\title{
Fertilization and Colors of Plastic Mulch Affect Biomass and Essential Oil of Sweet-Scented Geranium
}

\author{
Anderson de Carvalho Silva, ${ }^{1}$ Arie Fitzgerald Blank, ${ }^{1}$ Wallace Melo dos Santos, ${ }^{1}$ \\ Paloma Santana Prata, ${ }^{2}$ Péricles Barreto Alves, ${ }^{2}$ and Maria de Fátima Arrigoni-Blank ${ }^{1}$ \\ ${ }^{1}$ Department of Agronomic Engineering, Federal University of Sergipe, Avenida Marechal Rondon $s / n$, \\ 49100-000 Sao Cristovao, SE, Brazil \\ ${ }^{2}$ Department of Chemistry, Federal University of Sergipe, Avenida Marechal Rondon s/n, 49100-000 Sao Cristovao, SE, Brazil
}

Correspondence should be addressed to Maria de Fátima Arrigoni-Blank; fatima.blank@gmail.com

Received 4 December 2013; Accepted 3 February 2014; Published 16 March 2014

Academic Editors: P. B. Andrade and R. M. Mian

Copyright (C) 2014 Anderson de Carvalho Silva et al. This is an open access article distributed under the Creative Commons Attribution License, which permits unrestricted use, distribution, and reproduction in any medium, provided the original work is properly cited.

\begin{abstract}
Sweet-scented geranium (Pelargonium graveolens L'Hér), a plant belonging to the Geraniaceae family, has medicinal and aromatic properties and is widely used in the cosmetic, soap, perfume, aromatherapy, and food industries. The aim of this study was to evaluate the influence of fertilization and the use of different colors of plastic mulch on sweet-scented geranium biomass and essential oil. Three colors of plastic mulch (black, white, and silver-colored) and a control without plastic mulch were assessed along

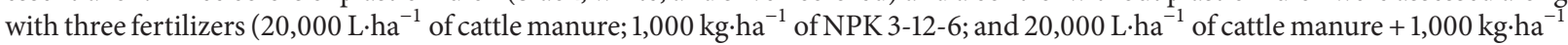
of NPK 3-12-6 fertilizer) and a control without fertilizer. The absence of a soil cover negatively influenced the agronomical variables, while coverage with plastic mulch was associated with increased biomass. The use of fertilizer had no effect on the evaluated agronomic variables. When cattle manure and NPK 3-12-6 were used together, combined with white or black plastic mulch, the highest yields of essential oil were obtained. For the silver-colored plastic mulch, higher amounts of essential oil (6,9-guaiadien) were obtained with mineral fertilizer.
\end{abstract}

\section{Introduction}

The Pelargonium (Geraniaceae) genus contains around 280 herbaceous, shrub, and subshrub species, including annuals and perennials that typically originated from southern Africa [1]. Pelargonium graveolens L'Hér is one of the most important species in this genus and is an aromatic shrub species that can reach up to $1.3 \mathrm{~m}$ in height. This geranium is native to Cape Province, South Africa, and is grown in many regions worldwide, including the Reunion Islands, Algeria, southern France, Spain, Morocco, Madagascar, Congo, and Russia, for the production of its essential oil [2-6]. The geranium essential oil is an important material for the cosmetic, soap, perfume, aromatherapy, and food industries [2, 7-10]. It is also used in popular medicines against dysentery, diarrhea, colds, and lung infections $[3,11]$.

The production of essential oils in plants may be altered by environmental or ontogenic factors, such as the physicalchemical characteristics of the soil, moisture, temperature, developmental stage, and phenology [12]. These factors have therefore been evaluated to determine how they influence the production of volatile compounds in medicinal and aromatic species [8, 13-15].

Soil composition is one of the determining factors for crop establishment and may be altered to meet the nutritional needs of plants. Agricultural inputs, namely, chemical or organic fertilizers, can be used for this purpose. Organic fertilizers naturally reset nutritional characteristics and rely on the production of organic matter by decomposition, which is an important source of nutrients for plants, microflora, and terrestrial fauna. In the soil, organic matter provides nutrients and has an important role as a conditioner of the physical, chemical, and biological properties of the soil [16]. The traditional cultivation of geranium combines chemical fertilizer and organic matter inputs. With respect to essential oil production, the cultivation of $P$. graveolens is more profitable when the crop is grown in soils rich in organic matter [17]. 
For the use of proper growth conditions and increase of the production of active constituents it is necessary to develop agricultural technologies for a correct cultivation of aromatic plants $[16,18]$. Mulching is a common technology used in the cultivation of medicinal and aromatic species to increase the production of active ingredients [19]. Among other benefits, the use of mulch regulates surface radiation, promotes vegetative growth and productivity, increases insect repellence, controls weeds, decreases water loss by evaporation, and facilitates harvesting [20].

The aim of this study was to evaluate the effect of organicmineral fertilizers and soil coverage with plastic mulch on sweet-scented geranium (P. graveolens) biomass and essential oil.

\section{Materials and Methods}

2.1. Plant Materials. Plants of sweet-scented geranium (Pelargonium graveolens L'Hér) genotype UFS-PEL001 were propagated by cuttings. The plants were maintained in $1500 \mathrm{~cm}^{3}$ plastic bags containing a $1: 1$ mixture of soil and sand as substrate for 30 days and then transplanted to the field. Genotype exsiccates were deposited in the ASE Herbarium of the Federal University of Sergipe (UFS), under the record number ASE-14844.

2.2. Experimental Procedure. The assay was conducted at the "Campus Rural da UFS" Research Farm, located in São Cristóvão, Sergipe State, Brazil, from 2008 to 2009. The climate of the region is tropical semiarid, and the soil is classified as Red-Yellow Argisol with low fertility. The chemical characteristics of the soil are as follows: $\mathrm{pH}=5.4$ in water; $P=2.3 \mathrm{mg} \cdot \mathrm{dm}^{-3} ; \mathrm{K}($ Mehlich 1$)=0.09 \mathrm{cmolc} \cdot \mathrm{dm}^{-3} ; \mathrm{Ca}+\mathrm{Mg}$ $[21]=2.70 \mathrm{cmolc} \cdot \mathrm{dm}^{-3} ;$ and organic matter $=21.1 \mathrm{~g} \cdot \mathrm{dm}^{-3}$.

A randomized block design was used for the experiment, with three replicates in a split-plot design. In the plots, three different colored plastic mulches (black, white, and silver-colored) were tested in addition to the control with no plastic mulch. In the subplots, three fertilizer treatments $\left(20,000 \mathrm{~L} \cdot \mathrm{ha}^{-1}\right.$ of cattle manure; $1,000 \mathrm{~kg} \cdot \mathrm{ha}^{-1}$ of NPK 3-12-6; and $20,000 \mathrm{~L} \cdot \mathrm{ha}^{-1}$ of cattle manure $+1,000 \mathrm{~kg} \cdot \mathrm{ha}^{-1}$ of NPK $3-$ 12-6) were tested in addition to the control without fertilizer. Fertilizer was applied 15 days before transplantation of the plants to the field.

The spacing between rows and between plants was $50 \mathrm{~cm}$. The beds were $90 \mathrm{~cm}$ wide, and each plot contained four plants cultivated in two rows. A drip irrigation system was used. Planting in the field was performed on May 28, and the first harvest was realized on August 26. Subsequent harvests were realized 90 days apart.

At each harvest, the height and canopy diameter of each plant was measured before cutting the plants and after cutting the fresh weight was measured. To determine the moisture content, three $100 \mathrm{~g}$ fresh leaf samples were dried in an oven dryer at $105^{\circ} \mathrm{C}$ until constant weight.

2.3. Essential Oils. The essential oils of the fresh leaves were obtained by steam distillation using a Clevenger apparatus
[22] for $2 \mathrm{~h}$ and $40 \mathrm{~min}$ [23]. The content percentage was estimated using the dry matter weight $(\mathrm{v} / \mathrm{m})$ of the three $100 \mathrm{~g}$ leaf samples.

2.4. Analysis of Essential Oils. The analysis of the essential oil chemical composition was performed in a gas chromatograph coupled to a mass spectrometer (GC-MS) (Shimadzu, model QP 5050A) equipped with an AOC-20i autoinjector (Shimadzu) and a fused-silica capillary column (5\%-phenyl$95 \%$-dimethylpolysiloxane, $30 \mathrm{~m} \times 0.25 \mathrm{~mm}$ id., $0.25 \mu \mathrm{m}$ film, J\&W Scientific). Helium was used as the carrier gas at a flow rate of $1.2 \mathrm{~mL} / \mathrm{min}$. The temperature program was as follows: $50^{\circ} \mathrm{C}$ for $1.5 \mathrm{~min}$, temperature increase at $4^{\circ} \mathrm{C} / \mathrm{min}$ until reaching $200^{\circ} \mathrm{C}$, temperature increase at $15^{\circ} \mathrm{C} / \mathrm{min}$ until reaching $250^{\circ} \mathrm{C}$, and $250^{\circ} \mathrm{C}$ for $5 \mathrm{~min}$. The injector temperature was $250^{\circ} \mathrm{C}$, and the detector (or interface) temperature was $280^{\circ} \mathrm{C}$. The injection volume of ethyl acetate was $0.5 \mu \mathrm{L}$, the partition rate of the injected volume was $1: 87$, and the column pressure was $64.20 \mathrm{kPa}$. The mass spectrometer conditions were as follows: ionic capture detector impact energy of $70 \mathrm{eV}$ and scanning speed $0.85 \mathrm{scan} / \mathrm{s}$ from 40 to $550 \mathrm{Da}$.

Quantitative analysis of the chemical constituents was performed by flame ionization gas chromatography (FID), using a Shimadzu GC-17A (Shimadzu Corporation, Kyoto, Japan) instrument, under the following operational conditions: capillary ZB-5MS column (5\% phenyl-arylene-95\%dimethylpolysiloxane) and fused-silica capillary column $(30 \mathrm{~m} \times 0.25 \mathrm{~mm}$ i.d. $\times 0.25 \mu \mathrm{m}$ film thickness) from Phenomenex (Torrance, CA, USA), under same conditions as reported for the GC-MS. Quantification of each constituent was estimated by area normalization (\%). Compound concentrations were calculated from the GC peak areas and they were arranged in order of GC elution.

The essential oil components were identified by comparing their mass spectra with the available spectra in the equipment database (NIST05 and WILEY8). Additionally, the measured retention indices were compared with those in the literature [24]. The relative retention indices (RRI) were determined using the Vandendool and Kratz [25] equation and a homologous series of $n$-alkanes $\left(\mathrm{C}_{8}-\mathrm{C}_{18}\right)$ injected under the chromatography conditions described above.

2.5. Statistical Analysis. We analyzed the following variables during the 12-month period: survival (\%), plant height $(\mathrm{cm})$, canopy diameter $(\mathrm{cm})$, leaf fresh weight $\left(\mathrm{g} \cdot\right.$ plant $\left.^{-1}\right)$, leaf moisture $(\%)$, essential oil content $(\%)$, and yield $\left(\mathrm{mL} \cdot\right.$ plant $\left.^{-1}\right)$. The content (\%) of the following chemical constituents was determined: citronellol, geraniol, citronellyl formate, linalool, 6,9-guaiadien, geranyl formate, geranial, and isomenthone.

The means of the variables were subjected to the analysis of variance $F$ test and were compared using the Scott-Knott test at $5 \%$ probability.

\section{Results}

3.1. Agronomical Variables. The use of plastic mulch is common in vegetable production, but the effect of this mulching 
TABLE 1: The effect of different colors of plastic mulch and fertilizers on content and yield of sweet-scented geranium essential oil.

\begin{tabular}{|c|c|c|c|c|}
\hline \multirow{2}{*}{ Fertilizer } & \multicolumn{4}{|c|}{ Colors of plastic mulch } \\
\hline & Control & White & Black & Silver-colored \\
\hline & \multicolumn{4}{|c|}{ Essential oil content (\%) } \\
\hline Control & $1.30^{\mathrm{aA}}$ & $1.42^{\mathrm{aA}}$ & $0.87^{\mathrm{aA}}$ & $1.16^{\mathrm{aA}}$ \\
\hline Cattle manure & $1.32^{\mathrm{aA}}$ & $1.51^{\mathrm{aA}}$ & $1.15^{\mathrm{aA}}$ & $0.96^{\mathrm{aA}}$ \\
\hline NPK 3-12-6 & $1.23^{\mathrm{aA}}$ & $1.14^{\mathrm{aA}}$ & $1.16^{\mathrm{aA}}$ & $1.26^{\mathrm{aA}}$ \\
\hline \multirow[t]{2}{*}{ Cattle manure + NPK 3-12-6 } & $1.30^{\mathrm{aA}}$ & $1.25^{\mathrm{aA}}$ & $1.08^{\mathrm{aA}}$ & $1.16^{\mathrm{aA}}$ \\
\hline & \multicolumn{4}{|c|}{ Essential oil yield $\left(\mathrm{mL} \cdot\right.$ plant $\left.^{-1}\right)$} \\
\hline Control & $0.32^{\mathrm{aA}}$ & $0.49^{\mathrm{aA}}$ & $0.26^{\mathrm{aA}}$ & $0.52^{\mathrm{aA}}$ \\
\hline Cattle manure & $0.21^{\mathrm{aB}}$ & $1.04^{\mathrm{aA}}$ & $0.42^{\mathrm{aB}}$ & $0.59^{\mathrm{aB}}$ \\
\hline NPK 3-12-6 & $0.21^{\mathrm{aA}}$ & $0.71^{\mathrm{aA}}$ & $0.45^{\mathrm{aA}}$ & $0.62^{\mathrm{aA}}$ \\
\hline Cattle manure + NPK 3-12-6 & $0.18^{\mathrm{aB}}$ & $1.02^{\mathrm{aA}}$ & $0.64^{\mathrm{aB}}$ & $0.97^{\mathrm{aA}}$ \\
\hline
\end{tabular}

Lowercase letters indicate differences within columns, and uppercase letters indicate differences within rows. Values followed by the same letter are not statistically different based on the Scott-Knott test $(P \leq 0.05)$.

approach has not been widely studied in medicinal and aromatic plants.

The results from the present study indicate that the interaction between the type of plastic mulch and the type of fertilizer was significant only for the yield of essential oil. The use of cattle manure alone or cattle manure + NPK 312-6, combined with white plastic mulch, produced a higher essential oil yield than did the same treatment with black or silver-colored plastic mulch (Table 1). As for the other variables, the lack of plastic mulch significantly reduced survival and leaf fresh weight and the essential oil yield of the plants from the first two harvests. For the third and fourth harvests, reductions were observed for all the variables (Table 2).

For the different fertilization treatments, there were no significant differences observed for the assessed variables (Table 1).

3.2. Essential Oils. The contents of several of the analyzed compounds varied significantly when different types of fertilizers were used. In addition, there were variations in compound content when the plants were grown under different colored plastic mulches (Table 3).

There was an interaction between the various factors of the contents of citronellol, geraniol, 6,9-guaiadien, geranial, and isomenthone. The citronellyl formate content was only affected by colors of plastic mulch. The linalool and geranyl formate contents were not affected by types of fertilizers and colors of plastic mulches (Table 3). Significant differences in citronellol content were observed for the different fertilizer treatments when no plastic mulch was used. In this case, the use of cattle manure as fertilizer led to an increased content of citronellol. There were significant differences in geraniol content for the different colors of plastic mulch with the NPK (3-12-6) and cattle manure + NPK (3-12-6) fertilizer treatments; greater geraniol content was observed when no plastic mulch was used compared to the other plastic mulch treatments. The citronellol content was greater when cattle manure was used as fertilizer, while geraniol production increased when NPK (3-12-6) was used.
The lowest contents of 6,9-guaiadien were observed with the silver-colored plastic mulch using no fertilizer or cattle manure for fertilizing (Table 3). The production of geranial was strongly reduced by two particular combinations: the use of a black plastic mulch with cattle manure and the use of a silver-colored plastic mulch with cattle manure + NPK 3-12-6 (Table 3). These observations highlight the negative influence of cattle manure combined with the plastic mulches on the geranial compound.

Significant differences were also observed for citronellyl formate content, which was reduced when the silver-colored plastic mulch was combined with cattle manure or without fertilizer. The isomenthone content was lowest when NPK 312-6 was combined with no plastic mulch and when cattle manure was combined with the black plastic mulch.

\section{Discussion}

The present evaluation of different colored plastic mulches demonstrates the effectiveness of mulching for geranium production in light of the fact that the control treatment (without mulch) resulted in lower values for almost all of the agronomic variables assessed. Plant development is certainly influenced by factors affected by the use of plastic mulch, such as moisture retention, reduced competition for light and nutrients due to the absence of weeds, a reduction of pests, and an increase in the surface temperature of the soil [26].

The findings of similar studies confirm these benefits, including the study of [27], which demonstrated a reduction in the productivity of cantaloupe when no plastic mulch was used. In experiments investigating the use of plastic mulch on potato crops, plants were found to emerge earlier, achieving greater height and tuber volume, when a plastic mulch was used on the soil $[28,29]$. In a study assessing five different plastic mulch colors (black, white, red, silver, and blue) on an okra crop, the greatest yield was obtained with the silvercolored plastic mulch, followed by the blue plastic mulch, while the control treatment with no mulch produced the lowest yield [30]. 
TABLE 2: The effect of different colors of plastic mulch and fertilizers on the survival and leaf fresh weight of sweet-scented geranium.

\begin{tabular}{|c|c|c|c|c|}
\hline \multicolumn{5}{|c|}{ Survival (\%) } \\
\hline \multirow{2}{*}{ Fertilizer } & \multicolumn{4}{|c|}{ Colors of plastic mulch } \\
\hline & Control & White & Black & Silver colored \\
\hline & \multicolumn{4}{|c|}{ First harvest } \\
\hline Control & $58.33^{\mathrm{Aa}}$ & $100.00^{\mathrm{Aa}}$ & $100.00^{\mathrm{Aa}}$ & $100.00^{\mathrm{Aa}}$ \\
\hline Cattle manure & $58.33^{\mathrm{Aa}}$ & $91,66^{\mathrm{Aa}}$ & $100.00^{\mathrm{Aa}}$ & $100.00^{\mathrm{Aa}}$ \\
\hline NPK 3-12-6 & $58.33^{\mathrm{Aa}}$ & $100.00^{\mathrm{Aa}}$ & $100.00^{\mathrm{Aa}}$ & $100.00^{\mathrm{Aa}}$ \\
\hline \multirow[t]{2}{*}{ Cattle manure + NPK 3-12-6 } & $25.00^{\mathrm{Bb}}$ & $100.00^{\mathrm{Aa}}$ & $100.00^{\mathrm{Aa}}$ & $100.00^{\mathrm{Aa}}$ \\
\hline & \multicolumn{4}{|c|}{ Second harvest } \\
\hline Control & $58.33^{\mathrm{Aa}}$ & $91.66^{\mathrm{Aa}}$ & $100.00^{\mathrm{Aa}}$ & $100.00^{\mathrm{Aa}}$ \\
\hline Cattle manure & $58.33^{\mathrm{Aa}}$ & $100.00^{\mathrm{Aa}}$ & $100.00^{\mathrm{Aa}}$ & $100.00^{\mathrm{Aa}}$ \\
\hline NPK 3-12-6 & $58.33^{\mathrm{Aa}}$ & $100.00^{\mathrm{Aa}}$ & $100.00^{\mathrm{Aa}}$ & $100.00^{\mathrm{Aa}}$ \\
\hline \multirow[t]{2}{*}{ Cattle manure + NPK 3-12-6 } & $16.66^{\mathrm{Ba}}$ & $100.00^{\mathrm{Aa}}$ & $100.00^{\mathrm{Aa}}$ & $100.00^{\mathrm{Aa}}$ \\
\hline & \multicolumn{4}{|c|}{ Third harvest } \\
\hline Control & $58.33^{\mathrm{Aa}}$ & $100.00^{\mathrm{Aa}}$ & $100.00^{\mathrm{Aa}}$ & $100.00^{\mathrm{Aa}}$ \\
\hline Cattle manure & $58.33^{\mathrm{Aa}}$ & $91.66^{\mathrm{Aa}}$ & $100.00^{\mathrm{Aa}}$ & $100.00^{\mathrm{Aa}}$ \\
\hline NPK 3-12-6 & $41.66^{\mathrm{Ba}}$ & $100.00^{\mathrm{Aa}}$ & $100.00^{\mathrm{Aa}}$ & $100.00^{\mathrm{Aa}}$ \\
\hline \multirow[t]{2}{*}{ Cattle manure + NPK 3-12-6 } & $16.66^{\mathrm{Bb}}$ & $91.66^{\mathrm{Aa}}$ & $100.00^{\mathrm{Aa}}$ & $100.00^{\mathrm{Aa}}$ \\
\hline & \multicolumn{4}{|c|}{ Fourth harvest } \\
\hline Control & $25.00^{\mathrm{Bb}}$ & $91.66^{\mathrm{Aa}}$ & $100.00^{\mathrm{Aa}}$ & $100.00^{\mathrm{Aa}}$ \\
\hline Cattle manure & $33.33^{\mathrm{Ba}}$ & $83.33^{\mathrm{Aa}}$ & $100.00^{\mathrm{Aa}}$ & $91.66^{\mathrm{Aa}}$ \\
\hline NPK 3-12-6 & $33.33^{\mathrm{Ba}}$ & $83.33^{\mathrm{Aa}}$ & $100.00^{\mathrm{Aa}}$ & $100.00^{\mathrm{Aa}}$ \\
\hline Cattle manure + NPK 3-12-6 & $25.00^{\mathrm{Bb}}$ & $91.66^{\mathrm{Aa}}$ & $50.00^{\mathrm{Bb}}$ & $100.00^{\mathrm{Aa}}$ \\
\hline \multicolumn{5}{|c|}{ Leaf fresh weight $\left(\mathrm{g} \cdot\right.$ plant $\left.^{-1}\right)$} \\
\hline \multirow{2}{*}{ Fertilizer } & \multicolumn{4}{|c|}{ Colors of plastic mulch } \\
\hline & Control & White & Black & Silver colored \\
\hline & \multicolumn{4}{|c|}{ First harvest } \\
\hline Control & $107.65^{\mathrm{aA}}$ & $164.33^{\mathrm{bA}}$ & $150.07^{\mathrm{aA}}$ & $303.09^{\mathrm{aA}}$ \\
\hline Cattle manure & $70.83^{\mathrm{Ba}}$ & $346.65^{\mathrm{Aa}}$ & $179.76^{\mathrm{Ba}}$ & $319.15^{\mathrm{Aa}}$ \\
\hline NPK 3-12-6 & $78.51^{\mathrm{Ba}}$ & $303.38^{\mathrm{Aa}}$ & $148.52^{\mathrm{Ba}}$ & $248.25^{\mathrm{Aa}}$ \\
\hline \multirow[t]{2}{*}{ Cattle manure + NPK 3-12-6 } & $62.53^{\mathrm{Ba}}$ & $374.98^{\mathrm{Aa}}$ & $261.36^{\mathrm{Aa}}$ & $363.86^{\mathrm{Aa}}$ \\
\hline & \multicolumn{4}{|c|}{ Second harvest } \\
\hline Control & $106.65^{\mathrm{Aa}}$ & $311.32^{\mathrm{Aa}}$ & $196.28^{\mathrm{Aa}}$ & $372.15^{\mathrm{Aa}}$ \\
\hline Cattle manure & $82.21^{\mathrm{Aa}}$ & $332.41^{\mathrm{Aa}}$ & $232.34^{\mathrm{Aa}}$ & $404.18^{\mathrm{Aa}}$ \\
\hline NPK 3-12-6 & $65.17^{\mathrm{Ba}}$ & $368.68^{\mathrm{Aa}}$ & $215.04^{\mathrm{Ba}}$ & $359.23^{\mathrm{Aa}}$ \\
\hline \multirow[t]{2}{*}{ Cattle manure + NPK 3-12-6 } & $23.28^{\mathrm{Ba}}$ & $299.97^{\mathrm{Aa}}$ & $272.50^{\mathrm{Aa}}$ & $305.56^{\mathrm{Aa}}$ \\
\hline & \multicolumn{4}{|c|}{ Third harvest } \\
\hline Control & $141.66^{\mathrm{Ba}}$ & $425.00^{\mathrm{Aa}}$ & $187.50^{\mathrm{Ba}}$ & $389.83^{\mathrm{Aa}}$ \\
\hline Cattle manure & $137.50^{\mathrm{Ba}}$ & $555.00^{\mathrm{Aa}}$ & $316.66^{\mathrm{Ba}}$ & $482.44^{\mathrm{Aa}}$ \\
\hline NPK 3-12-6 & $136.11^{\mathrm{Aa}}$ & $434.16^{\mathrm{Aa}}$ & $326.66^{\mathrm{Aa}}$ & $334.71^{\mathrm{Aa}}$ \\
\hline \multirow[t]{2}{*}{ Cattle manure + NPK 3-12-6 } & $21.66^{\mathrm{Ba}}$ & $456.39^{\mathrm{Aa}}$ & $324.16^{\mathrm{Aa}}$ & $451.29^{\mathrm{Aa}}$ \\
\hline & \multicolumn{4}{|c|}{ Fourth harvest } \\
\hline Control & $23.33^{\mathrm{Aa}}$ & $23.33^{\mathrm{Aa}}$ & $141.66^{\mathrm{Aa}}$ & $269.16^{\mathrm{Aa}}$ \\
\hline Cattle manure & $55.00^{\mathrm{Aa}}$ & $55.00^{\mathrm{Aa}}$ & $183.99^{\mathrm{Aa}}$ & $207.50^{\mathrm{Aa}}$ \\
\hline NPK 3-12-6 & $63.33^{\mathrm{Aa}}$ & $63.33^{\mathrm{Aa}}$ & $203.33^{\mathrm{Aa}}$ & $138.33^{\mathrm{Aa}}$ \\
\hline Cattle manure + NPK 3-12-6 & $150.00^{\mathrm{Aa}}$ & $150.00^{\mathrm{Aa}}$ & $216.66^{\mathrm{Aa}}$ & $289.16^{\mathrm{Aa}}$ \\
\hline
\end{tabular}

Lowercase letters indicate differences within columns, and uppercase letters indicate differences within rows. Values followed by the same letter are not statistically different based on the Scott-Knott test $(P \leq 0.05)$. 
TABLE 3: The effects of different colors of plastic mulch and fertilizers on contents of citronellol, geraniol, citronellyl formate, linalool, 6,9guaiadien, geranyl formate, geranial, and isomenthone in sweet-scented geranium essential oil.

\begin{tabular}{|c|c|c|c|c|}
\hline \multirow{2}{*}{ Fertilizer } & \multicolumn{4}{|c|}{ Colors of plastic mulch } \\
\hline & Control & White & Black & Silver-colored \\
\hline & \multicolumn{4}{|c|}{ Citronellol $(\%)(\mathrm{RRI}=1223)$} \\
\hline Control & $24.68^{\mathrm{bB}}$ & $28.18^{\mathrm{aA}}$ & $26.95^{\mathrm{aB}}$ & $30.42^{\mathrm{aA}}$ \\
\hline Cattle manure & $29.44^{\mathrm{aA}}$ & $29.46^{\mathrm{aA}}$ & $31.22^{\mathrm{aA}}$ & $28.72^{\mathrm{aA}}$ \\
\hline NPK 3-12-6 & $25.14^{\mathrm{bB}}$ & $30.56^{\mathrm{aA}}$ & $28.73^{\mathrm{aA}}$ & $29.00^{\mathrm{aA}}$ \\
\hline \multirow[t]{2}{*}{ Cattle manure + NPK 3-12-6 } & $23.68^{\mathrm{bB}}$ & $29.44^{\mathrm{aA}}$ & $29.61^{\mathrm{aA}}$ & $30.64^{\mathrm{aA}}$ \\
\hline & \multicolumn{4}{|c|}{ Geraniol $(\%)(\mathrm{RRI}=1249)$} \\
\hline Control & $20.85^{\mathrm{aA}}$ & $17.99^{\mathrm{aA}}$ & $19.88^{\mathrm{aA}}$ & $19.04^{\mathrm{aA}}$ \\
\hline Cattle manure & $18.99^{\mathrm{aA}}$ & $19.39^{\mathrm{aA}}$ & $20.63^{\mathrm{aA}}$ & $20.28^{\mathrm{aA}}$ \\
\hline NPK 3-12-6 & $21.86^{\mathrm{aA}}$ & $17.80^{\mathrm{aB}}$ & $18.21^{\mathrm{aB}}$ & $16.66^{\mathrm{aB}}$ \\
\hline \multirow[t]{2}{*}{ Cattle manure + NPK 3-12-6 } & $24.72^{\mathrm{aA}}$ & $18.99^{\mathrm{aB}}$ & $18.99^{\mathrm{aB}}$ & $18.49^{\mathrm{aB}}$ \\
\hline & \multicolumn{4}{|c|}{ Citronellyl formate $(\%)(\mathrm{RRI}=1271)$} \\
\hline Control & $11.16^{\mathrm{aA}}$ & $10.97^{\mathrm{aA}}$ & $11.40^{\mathrm{aA}}$ & $12.00^{\mathrm{bA}}$ \\
\hline Cattle manure & $11.69^{\mathrm{aA}}$ & $11.67^{\mathrm{aA}}$ & $12.15^{\mathrm{aA}}$ & $10.69^{\mathrm{bA}}$ \\
\hline NPK 3-12-6 & $11.11^{\mathrm{aA}}$ & $11.87^{\mathrm{aA}}$ & $12.16^{\mathrm{aA}}$ & $14.28^{\mathrm{aA}}$ \\
\hline \multirow[t]{2}{*}{ Cattle manure + NPK 3-12-6 } & $9.54^{\mathrm{aA}}$ & $11.69^{\mathrm{aA}}$ & $12.52^{\mathrm{aA}}$ & $14.61^{\mathrm{aA}}$ \\
\hline & \multicolumn{4}{|c|}{ Linalool $(\%)(\mathrm{RRI}=1095)$} \\
\hline Control & $12.36^{\mathrm{aA}}$ & $11.80^{\mathrm{aA}}$ & $10.00^{\mathrm{aA}}$ & $10.89^{\mathrm{aA}}$ \\
\hline Cattle manure & $10.31^{\mathrm{aA}}$ & $11.42^{\mathrm{aA}}$ & $10.06^{\mathrm{aA}}$ & $8.99^{\mathrm{aA}}$ \\
\hline NPK 3-12-6 & $9.95^{\mathrm{aA}}$ & $13.08^{\mathrm{aA}}$ & $13.55^{\mathrm{aA}}$ & $12.82^{\mathrm{aA}}$ \\
\hline \multirow[t]{2}{*}{ Cattle manure + NPK 3-12-6 } & $11.63^{\mathrm{aA}}$ & $10.31^{\mathrm{aA}}$ & $12.66^{\mathrm{aA}}$ & $9.90^{\mathrm{aA}}$ \\
\hline & \multicolumn{4}{|c|}{ 6,9-guaiadien $(\%)(\mathrm{RRI}=1442)$} \\
\hline Control & $6.19^{\mathrm{aA}}$ & $5.95^{\mathrm{aA}}$ & $5.74^{\mathrm{aA}}$ & $4.39^{\mathrm{bB}}$ \\
\hline Cattle manure & $6.02^{\mathrm{aA}}$ & $4.93^{\mathrm{aA}}$ & $4.84^{\mathrm{aA}}$ & $4.56^{\mathrm{bA}}$ \\
\hline NPK 3-12-6 & $5.93^{\mathrm{aA}}$ & $5.46^{\mathrm{aA}}$ & $5.68^{\mathrm{aA}}$ & $6.10^{\mathrm{aA}}$ \\
\hline \multirow[t]{2}{*}{ Cattle manure + NPK 3-12-6 } & $5.07^{\mathrm{aA}}$ & $6.02^{\mathrm{aA}}$ & $5.04^{\mathrm{aA}}$ & $5.87^{\mathrm{aA}}$ \\
\hline & \multicolumn{4}{|c|}{ Geranyl formate $(\%)(\mathrm{RRI}=1298)$} \\
\hline Control & $3.50^{\mathrm{aA}}$ & $3.48^{\mathrm{aA}}$ & $4.10^{\mathrm{aA}}$ & $4.12^{\mathrm{aA}}$ \\
\hline Cattle manure & $3.63^{\mathrm{aA}}$ & $3.73^{\mathrm{aA}}$ & $3.55^{\mathrm{aA}}$ & $3.79^{\mathrm{aA}}$ \\
\hline NPK 3-12-6 & $3.25^{\mathrm{aA}}$ & $3.12^{\mathrm{aA}}$ & $3.91^{\mathrm{aA}}$ & $4.62^{\mathrm{aA}}$ \\
\hline \multirow[t]{2}{*}{ Cattle manure + NPK 3-12-6 } & $3.39^{\mathrm{aA}}$ & $3.63^{\mathrm{aA}}$ & $3.29^{\mathrm{aA}}$ & $5.64^{\mathrm{aA}}$ \\
\hline & \multicolumn{4}{|c|}{ Geranial $(\%)(\mathrm{RRI}=1264)$} \\
\hline Control & $1.12^{\mathrm{aA}}$ & $1.29^{\mathrm{aA}}$ & $1.33^{\mathrm{aA}}$ & $1.12^{\mathrm{aA}}$ \\
\hline Cattle manure & $1.18^{\mathrm{aA}}$ & $0.79^{\mathrm{aA}}$ & $0.00^{\mathrm{bB}}$ & $1.26^{\mathrm{aA}}$ \\
\hline NPK 3-12-6 & $1.18^{\mathrm{aA}}$ & $1.13^{\mathrm{aA}}$ & $1.20^{\mathrm{aA}}$ & $1.08^{\mathrm{aA}}$ \\
\hline \multirow[t]{2}{*}{ Cattle manure + NPK 3-12-6 } & $1.12^{\mathrm{aA}}$ & $1.19^{\mathrm{aA}}$ & $1.16^{\mathrm{aA}}$ & $0.30^{\mathrm{bB}}$ \\
\hline & \multicolumn{4}{|c|}{ Isomenthone $(\%)(\mathrm{RRI}=1158)$} \\
\hline Control & $1.23^{\mathrm{aA}}$ & $1.40^{\mathrm{aA}}$ & $1.24^{\mathrm{aA}}$ & $1.37^{\mathrm{aA}}$ \\
\hline Cattle manure & $1.18^{\mathrm{aA}}$ & $1.18^{\mathrm{aA}}$ & $0.93^{\mathrm{bA}}$ & $1.24^{\mathrm{aA}}$ \\
\hline NPK 3-12-6 & $0.99^{\mathrm{aB}}$ & $1.40^{\mathrm{aA}}$ & $1.31^{\mathrm{aA}}$ & $1.31^{\mathrm{aA}}$ \\
\hline Cattle manure + NPK 3-12-6 & $1.18^{\mathrm{aA}}$ & $1.18^{\mathrm{aA}}$ & $1.25^{\mathrm{aA}}$ & $1.32^{\mathrm{aA}}$ \\
\hline
\end{tabular}

RRI: relative retention index.

Lowercase letters indicate differences within columns, and uppercase letters indicate differences within rows. Values followed by the same letter are not statistically different based on the Scott-Knott test $(P \leq 0.05)$.

Moreover, studies evaluating the effects of other factors associated with soil coverage, such as changes in the soil microclimate and the incidence of agricultural pests, demonstrate how the use of plastic mulch can be advantageous and economical for producers [31-33].
In Melissa officinalis L. soil coverage, with either pine needles or black plastic mulch, improved the biomass and essential oil yields [34]. In a related study in patchouli (Pogostemon cablin (Blanco) Benth.), the use of organic mulch for soil coverage improved the yield, amount, and quality of the 
patchouli essential oil [35]. In $P$ graveolens, an absence of soil coverage was associated with reduced yield and essential oil content along with changes in the contents of the major components of the essential oil [18]. In the present study, different fertilizer treatments did not influence the cultivation of geranium; this finding is probably due to the low nutritional requirements of the crop and its tolerance of acidic soils. It is likely that the existing nutrients in the soil sufficiently supported the crop during the evaluation period. On the other hand, when different levels of nitrogen fertilizer were tested in P. graveolens, significant differences were observed for the biomass and essential oil yield and content [18]. In a related study in Ocimum basilicum L. the use of organic-mineral fertilizer did not significantly influence the development of the plants or the production of essential oil [36]. Gopichand et al. [37] similarly observed that different levels of organic fertilizer did not significantly affect the development, yield, and essential oil content of Curcuma aromatica.

The results of the present study suggest that the interaction observed among the various factors and the changes in the contents of the major components of the geranium essential oil were due to the benefits provided by the plastic mulch: the temperature and humidity of the soil were maintained, and the resources necessary for the biosynthesis of secondary metabolites were available to the plants. The high contents of the essential oil and its major components in treatments where a plastic cover was used are in accordance with the data found in the literature.

\section{Conclusions}

The absence of a soil cover negatively influenced the agronomical variables, while coverage with plastic mulch was associated with increased biomass. When cattle manure and NPK 3-12-6 were used together, combined with white or black plastic mulch, the highest yields of essential oil were obtained. For the silver-colored plastic mulch, higher amounts of essential oil (6,9-guaiadien) were obtained with mineral fertilizer.

\section{Conflict of Interests}

The authors declare that there is no conflict of interests regarding the publication of this paper.

\section{Acknowledgments}

The authors thank FAPITEC/SE, CNPq, CAPES, and RENORBIO for their financial support of this work.

\section{References}

[1] F. T. Bakker, A. Culham, P. Hettiarachi, T. Touloumenidou, and M. Gibby, "Phylogeny of Pelargonium (Geraniaceae) based on DNA sequences from three genomes," Taxon, vol. 53, no. 1, pp. 17-28, 2004.

[2] M. Lis-Balchin and S. G. Deans, "Antimicrobial effects of hydrophilic extracts of Pelargonium species (Geraniaceae)," Letters in Applied Microbiology, vol. 23, no. 4, pp. 205-207, 1996.
[3] M. Lis-Balchin, J. Patel, and S. Hart, "Studies on the mode of action of essential oils of scented-leaf Pelargonium (Geraniaceae)," Phytotherapy Research, vol. 12, pp. 215-2217, 1998.

[4] M. Lis-Balchin, G. Buchbauer, T. Hirtenlehner, and M. Resch, "Antimicrobial activity of Pelargonium essential oils added to a quiche filling as a model food system," Letters in Applied Microbiology, vol. 27, no. 4, pp. 207-210, 1998.

[5] M. Lis-Balchin, G. Buchbauer, K. Ribisch, and M.-T. Wenger, "Comparative antibacterial effects of novel Pelargonium essential oils and solvent extracts," Letters in Applied Microbiology, vol. 27, no. 3, pp. 135-141, 1998.

[6] V. S. Rana, J. P. Juyal, and M. A. Blazquez, "Chemical constituents of essential oil of Pelargonium graveolens leaves," International Journal of Aromatherapy, vol. 12, no. 4, pp. 216218, 2002.

[7] B. R. R. Rao, P. N. Kaul, G. R. Mallavarapu, and S. Ramesh, "Effect of seasonal climatic changes on biomass yield and terpenoid composition of rose-scented geranium (Pelargonium species)," Biochemical Systematics and Ecology, vol. 24, no. 7-8, pp. 627-635, 1996.

[8] B. R. R. Rao, "Cultivation and distillation of geranium oil from Pelargonium species in India," in Geranium and Pelargonium: The Genera Geranium and Pelargonium, M. Lis-Balchin, Ed., pp. 212-2217, Taylor \& Francis, New York, NY, USA.

[9] H. R. Juliani, A. Koroch, J. E. Simon et al., "Quality of geranium oils (Pelargonium species): case studies in Southern and Eastern Africa," Journal of Essential Oil Research, vol. 18, pp. 116-121, 2006.

[10] N. M. Motsa, P. Soundy, J. M. Steyn, R. A. Learmonth, N. Mojela, and C. Teubes, "Plant shoot age and temperature effects on essential oil yield and oil composition of rose-scented geranium (Pelargonium sp.) grown in South Africa," Journal of Essential Oil Research, vol. 18, pp. 106-110, 2006.

[11] O. Kayser, K. Lattè, H. Kolodiziej, and F. J. Hammerschmidt, "Composition of the essential oils of Pelargonium sidoides DC. and Pelargonium reniforme Curt," Flavour and Fragrance Journal, vol. 13, pp. 209-2212, 1998.

[12] N. S. Sangwan, A. H. A. Farooqi, F. Shabih, and R. S. Sangwan, "Regulation of essential oil production in plants," Plant Growth Regulation, vol. 34, no. 1, pp. 3-21, 2001.

[13] B. R. R. Rao, "Biomass and essential oil yields of cornmint (Mentha arvensis L. f. piperascens Malinvaud ex Holmes) planted in different months in semi-arid tropical climate," Industrial Crops and Products, vol. 10, no. 2, pp. 107-113, 1999.

[14] J. L. S. Carvalho-Filho, A. F. Blank, P. B. Alves et al., "Influence of the harvesting time, temperature and drying period on basil (Ocimum basilicum L.) essential oil," Brazilian Journal of Pharmacology, vol. 16, pp. 24-230, 2006.

[15] B. K. Eiasu, J. M. Steyn, and P. Soundy, "Rose-scented geranium (Pelargonium capitatum $\times P$. radens) growth and essential oil yield response to different soil water depletion regimes," Agricultural Water Management, vol. 96, no. 6, pp. 991-1000, 2009.

[16] A. F. Blank, M. F. Arrigoni-Blank, V. F. Amancio, M. C. Mendonça, and L. G. M. Santana Filho, "Densidades de plantio e doses de biofertilizante na produção de capim-limão," Horticultura Brasileira, vol. 25, pp. 343-3349, 2007.

[17] F. E. Demarne, "Rose-scented geranium' a Pelargonium grown for the perfume industry," in Geranium and Pelargonium: The Genera Geranium and Pelargonium, M. Lis-Balchin, Ed., pp. 193-1211, Taylor \& Francis, New York, NY, USA, 2002. 
[18] M. R. A. Santos and R. Innecco, "Adubação orgânica e altura de corte da erva-cidreira brasileira," in Horticultura Brasileira, vol. 22, pp. 182-1185, 2004.

[19] M. Ram, D. Ram, and S. K. Roy, "Influence of an organic mulching on fertilizer nitrogen use efficiency and herb and essential oil yields in geranium (Pelargonium graveolens)," Bioresource Technology, vol. 87, no. 3, pp. 273-278, 2003.

[20] F. A. S. B. Medeiros, J. F. Medeiros, M. C. C. Silva, L. P. Alves, T. H. Souza, and S. L. A. Levien, "Necessidade hídrica do meloeiro irrigado com água de diferentes salinidades e cultivado com ou sem cobertura do solo," Revista Brasileira de Engenharia Agrícola e Ambiental, vol. 9, pp. 234-238, 2005.

[21] EMBRAPA-Serviço Nacional de Levantamento e Conservação dos Solos, "Manual de métodos de análise de solo," EMBRAPA, Rio de Janeiro, Brasil, 1979.

[22] E. Guenther, - Individual Essential Oils of the Plant Families Rutaceae and Labiatae, vol. 3 of The Essential Oils, Krieger, Fla, USA, Malabar, 1972.

[23] P. A. D. Ehlert, A. F. Blank, M. F. Arrigoni-Blank, J. W. A. Paula, D. A. Campos, and C. S. Alviano, "Tempo de hidrodestilação na extração de óleo essencial de sete espécies de plantas medicinais," Revista Brasileira de Plantas Medicinais, vol. 8, no. 2, pp. 79-80, 2006.

[24] R. P. Adams, Identification of Essential Oil Components by Gas Chromatograpy/Mass Spectroscopy, Allured, Carol Stream, Ill, USA, 4th edition, 2007.

[25] H. Vandendool and P. D. Kratz, "A generalization of the retention index system including linear temperature programmed gas-liquid partition chromatography," Journal of Chromatography, vol. 11, pp. 463-471, 1963.

[26] M. C. Mendonça, M. F. Santos, R. A. Simões, R. Silva-Mann, and A. F. Blank, "Production and entomofauna associated to lemon balm (Melissa officinalis L.) cultivated with synthetic mulch," Revista Brasileira de Plantas Medicinais, vol. 8, no. 1, pp. 63-67, 2005.

[27] M. Z. Negreiros, F. A. Costa, J. F. Medeiros, V. B. R. M.M. Leitão, F. Bezerra Neto, and J. E. Sobrinho, "Rendimento e qualidade do melão sob lâminas de irrigação e cobertura do solo com filmes de polietileno de diferentes cores," Horticultura Brasileira, vol. 23, pp. 773-7779, 2005.

[28] Y. Wang, Z. Xie, S. S. Malhi, C. L. Vera, Y. Zhang, and J. Wang, "Effects of rainfall harvesting and mulching technologies on water use efficiency and crop yield in the semi-arid Loess Plateau, China," Agricultural Water Management, vol. 96, no. 3, pp. 374-382, 2009.

[29] X.-Y. Hou, F.-X. Wang, J.-J. Han, S.-Z. Kang, and S.-Y. Feng, "Duration of plastic mulch for potato growth under drip irrigation in an arid region of Northwest China," Agricultural and Forest Meteorology, vol. 150, no. 1, pp. 115-121, 2010.

[30] G. G. Gordon, W. G. Foshee III, S. T. Reed, J. E. Brown, and E. L. Vinson III, "The effects of colored plastic mulches and row covers on the growth and yield of okra," Horticulture Technology, vol. 20, no. 1, pp. 224-233, 2010.

[31] T. Tuovinen, A. Kikas, T. Tolonen, and P. Kivijärvi, "Organic mulches vs. black plastic in organic strawberry: does it make a difference for ground beetles (Col., Carabidae)?" Journal of Applied Entomology, vol. 130, no. 9-10, pp. 495-503, 2006.

[32] Y.-C. Tan, J.-S. Lai, K. R. Adhikari, S. M. Shakya, A. K. Shukla, and K. R. Sharma, "Efficacy of mulching, irrigation and nitrogen applications on bottle gourd and okra for yield improvement and crop diversification," Irrigation and Drainage Systems, vol. 23, no. 1, pp. 25-41, 2009.
[33] D. Chakraborty, R. N. Garg, R. K. Tomar et al., "Synthetic and organic mulching and nitrogen effect on winter wheat (Triticum aestivum L.) in a semi-arid environment," Agricultural Water Management, vol. 97, no. 5, pp. 738-748, 2010.

[34] L. A. Biasi, A. P. J. Kowalski, D. Signor, M. A. Alves, F. I. Lima, and C. Deschamps, "Tipos de cobertura do solo e épocas de colheita na produção de melissa," Horticultura Brasileira, vol. 27, pp. 314-318, 2009.

[35] M. Singh, S. Sharma, and S. Ramesh, "Herbage, oil yield and oil quality of patchouli [Pogostemon cablin (Blanco) Benth.] influenced by irrigation, organic mulch and nitrogen application in semi-arid tropical climate," Industrial Crops and Products, vol. 16, no. 2, pp. 101-107, 2002.

[36] A. F. Blank, S. M. Fontes, A. S. Oliveira, M. C. Mendonça, R. Silva-Mann, and M. F. Arrigoni-Blank, "Produção de mudas, altura e intervalo de corte em melissa," Horticultura Brasileira, vol. 23, pp. 480-4484, 2005.

[37] G. Gopichand, R. D. Singh, R. L. Meena et al., "Effect of manure and plant spacing on crop growth, yield and oil-quality of Curcuma aromatica Salisb. in mid hill of western Himalaya," Industrial Crops and Products, vol. 24, no. 2, pp. 105-112, 2006. 


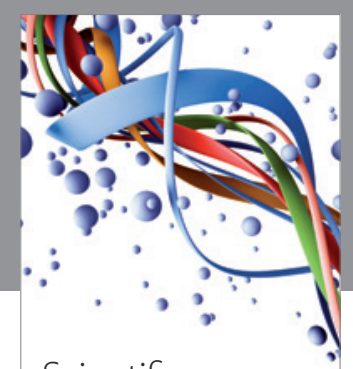

Scientifica
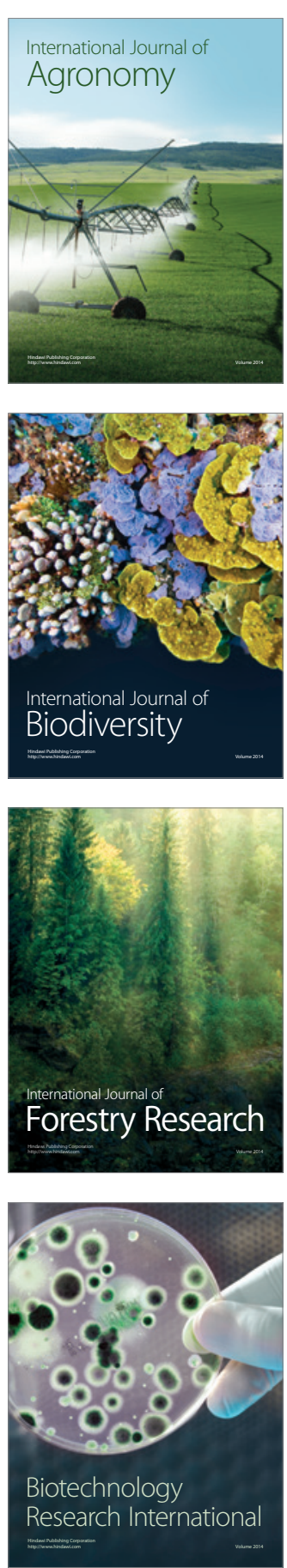
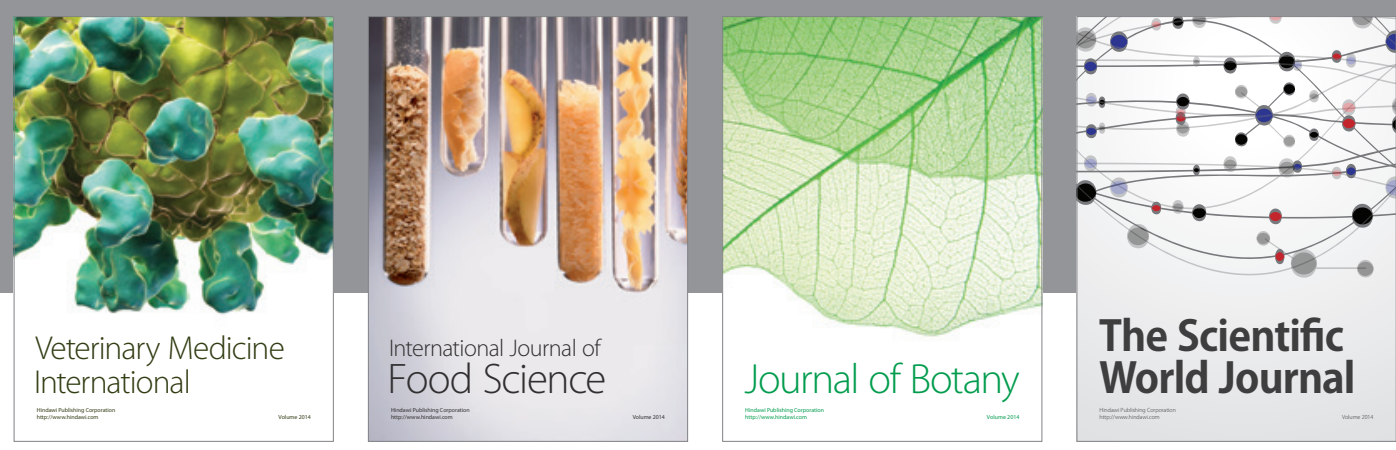

The Scientific World Journal
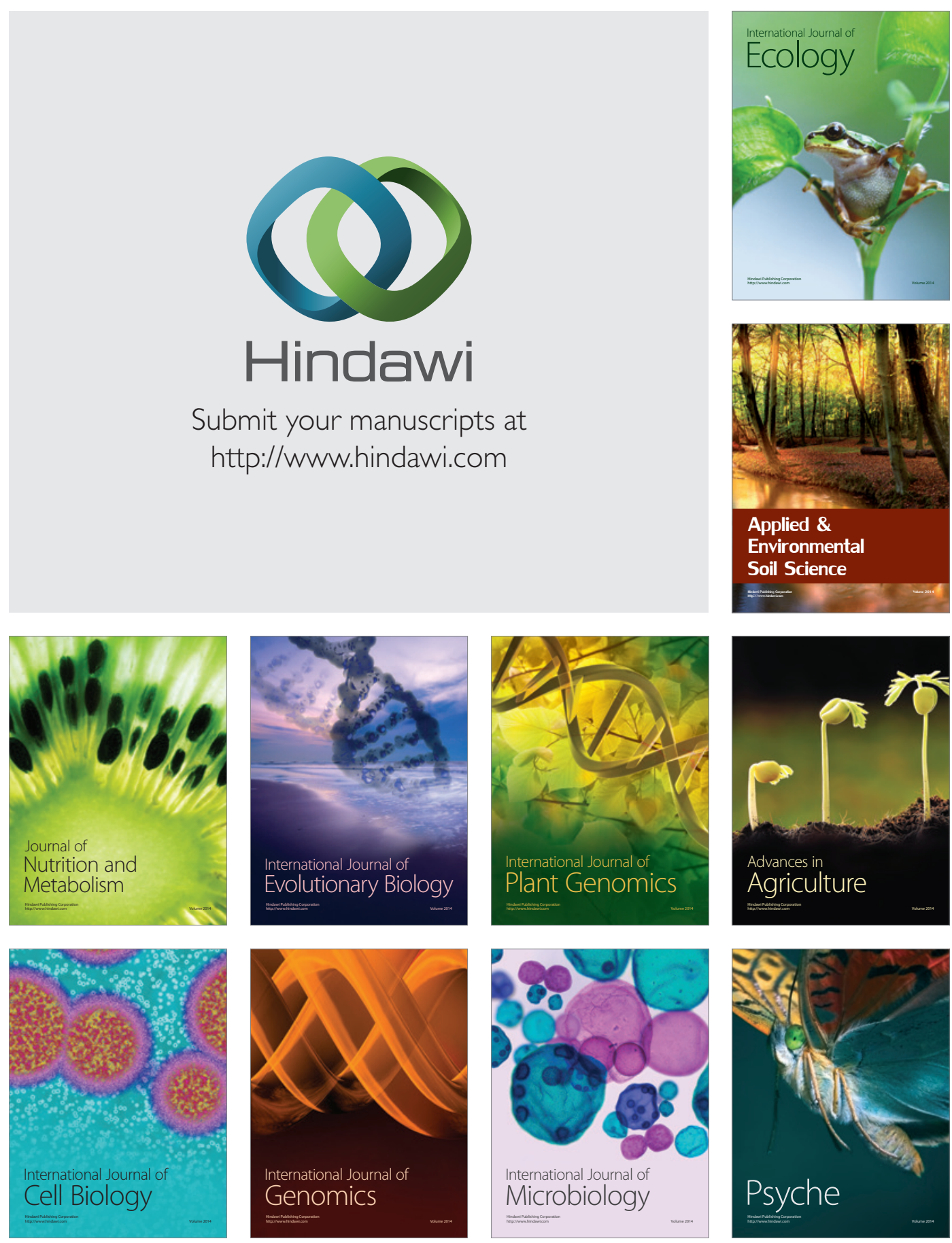